\title{
Gas Chromatographic-Mass Spectrometric Analysis of Polycyclic Aromatic Hydrocarbon Metabolites in Antarctic Fish (Notothenia gibberifrons) Injected with Diesel Fuel Arctic
}

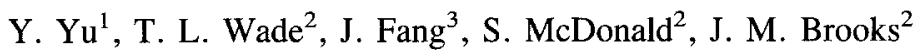 \\ ${ }^{1}$ Cincinnati Water Works, 5651 Kellogg Avenue, Cincinnati, Ohio 45228, USA \\ ${ }^{2}$ Geochemical and Environmental Research Group, Texas A\&M University, 833 Graham Road, College Station, Texas 77845, USA \\ ${ }^{3}$ National Center for Integrated Bioremediation Research and Development, Department of Civil and Environmental Engineering, The University of \\ Michigan, Ann Arbor, Michigan 48107, USA
}

Received: 19 September 1994/Revised: 20 January 1995

\begin{abstract}
Fish (Notothenia gibberifrons) collected in pristine Antarctic sites were injected with Diesel Fuel Arctic (DFA). Gas chromatography/mass spectrometry (GC/MS) was used to identify and quantify polycyclic aromatic hydrocarbon $(\mathrm{PAH})$ metabolites obtained from hydrolyzed fish bile. The concentrations of naphthols (NPH), phenanthrenols (PHN), dibenzothiophenols (DBT), and total PAH metabolites ( $\mathrm{PAH})$ vary with time. The response curve (production of PAH metabolites vs. time) resembled a Sigmoid curve, with an initial low response at $24 \mathrm{~h}$ followed by a rapid rise in production of PAH metabolites $(55.74 \mu \mathrm{g} / \mathrm{g}) 120 \mathrm{~h}$ after exposure to DFA. PAH metabolites identified include NPH, PHN, and DBT and their alkylated derivatives, reflecting the composition of the DFA to which the fish were exposed. The GC/MS technique is highly sensitive, particularly in the detection of multi-ring PAH metabolites. The results suggest that analysis of PAH metabolites is a valuable tool for environmental monitoring and assessment of exposure to petroleum.
\end{abstract}

Virtually all organisms possess biotransformation or detoxication enzymes which convert lipophilic xenobiotics to watersoluble and excretable metabolites (Livingston 1993). In the metabolic process, PAH are altered by phase I metabolism into various products such as epoxides, phenols, quinones, dihydrodiols, dihydrodiol epoxides, tetrahydrotriols, and tetrahydrotetrols (e.g., Varanasi and Gmur 1980). In phase II metabolism, these products are converted into highly water-soluble conjugates with a large water-soluble moiety, such as the tripeptide glutathione or sugar derivative glucuronic acid (Hellou and Payne 1978). The composition and concentrations of PAH metabolites in fish bile would thus be expected to indicate

Correspondence to: $\mathrm{Y} . \mathrm{Yu}$ the extent of PAH exposure and the degree of exposure of fish to PAH (Krahn et al. 1992).

Diesel Fuel Arctic (DFA) is a refined oil that contains semivolatile aromatic hydrocarbons such as naphthalenes and fluorenes (Kennicutt et al. 1991). In this study, DFA was administered by intramuscular (i.m.) injection to Antarctic fish (Notothenia gibberifrons). Biliary PAH metabolites were identified and quantified by gas chromatography/mass spectrometery techniques (Yu 1994). The objective of this study was to determine if the analysis of bile metabolites can be used as a reliable tool for monitoring and assessment studies of petroleum hydrocarbon contamination.

\section{Materials and Methods}

\section{Collection of Fish}

The fish (Notothenia gibberifrons) were caught at pristine sites in Low Island and Dallman Bay, Antarctic (McDonald et al. 1992), using an otter trawl, in March, 1991. Fish were transported in chilled sea water to the laboratory for further processing.

\section{Exposure of Fish to Diesel Fuel Arctic (DFA)}

Fish were maintained in running tap water at $-1.5^{\circ} \mathrm{C}$ to $1.0^{\circ} \mathrm{C}$ in $5 \mathrm{ft}$ diameter outdoor flow-through tanks. Fish were acclimatized for 1 week prior to initiation of the dosing experiment. The DFA $(100 \mu \mathrm{L})$ was administered by intramuscular injection (i.m.). The fish were not fed after injection. Fish were sacrificed for analysis at 0 (served as control point), $12,24,36,72,96$, and $120 \mathrm{~h}$ after dosing. The gallbladder was removed immediately and stored at $-60^{\circ} \mathrm{C}$ in amber vials until analysis.

\section{Enzymatic and Acidic Hydrolysis and Extraction of Biliary Metabolites}

Biliary conjugated (water-soluble) PAH metabolites were incubated with $\beta$-glucuronidase and aryl sulfates to cleave either glucuronide 
Table 1. Mass fragments and intensities of ions of polycyclic aromatic hydrocarbon (PAH) metabolites

\begin{tabular}{|c|c|c|c|c|c|}
\hline \multirow{2}{*}{$\frac{\text { Compound }}{\text { Naphthols }}$} & \multicolumn{2}{|l|}{$\mathrm{M}+(\mathrm{m} / \mathrm{z})^{\mathrm{a}}$} & \multicolumn{3}{|c|}{ Other fragment ions $(\mathrm{m} / \mathrm{z})$} \\
\hline & & & & & \\
\hline $\mathrm{CO}^{\mathrm{b}}$ & $216(100)^{c}$ & $201(85)$ & $185(50)$ & $137(35)$ & \\
\hline $\mathrm{C} 1^{\mathrm{d}}$ & $230(35)$ & $215(33)$ & $141(100)$ & $73(39)$ & \\
\hline $\mathrm{C} 2^{\mathrm{e}}$ & $244(100)$ & $229(64)$ & $214(35)$ & $199(23)$ & $73(33)$ \\
\hline $\mathrm{C} 3^{\mathrm{f}}$ & $258(14)$ & $243(12)$ & $191(11)$ & $169(100)$ & 73 (13) \\
\hline \multicolumn{6}{|c|}{ Phenylphenols } \\
\hline $\mathrm{CO}$ & $242(100)$ & $227(88)$ & $211(65)$ & $152(27)$ & $113(27)$ \\
\hline $\mathrm{C} 1$ & $256(47)$ & $241(43)$ & $211(54)$ & $167(100)$ & \\
\hline $\mathrm{C} 2$ & $270(23)$ & $255(56)$ & $225(8)$ & $181(100)$ & $73(15)$ \\
\hline C3 & $284(59)$ & $269(98)$ & $195(100)$ & $73(74)$ & \\
\hline \multicolumn{6}{|l|}{ Fluorenols } \\
\hline $\mathrm{CO}$ & $254(48)$ & 239 & $165(100)$ & $73(37)$ & \\
\hline $\mathrm{Cl}$ & $268(15)$ & $253(10)$ & $178(100)$ & $73(42)$ & \\
\hline $\mathrm{C} 2$ & $282(100)$ & $267(27)$ & $251(12)$ & $192(39)$ & \\
\hline $\mathrm{C} 3$ & $296(100)$ & 281 & $233(33)$ & $185(21)$ & \\
\hline \multicolumn{6}{|c|}{ Phenanthrenols/anthracenols } \\
\hline $\mathrm{CO}$ & $266(100)$ & 251 & 235 & $73(50)$ & \\
\hline $\mathrm{Cl}$ & $280(65)$ & 265 & $191(100)$ & $165(21)$ & $73(29)$ \\
\hline $\mathrm{C} 2$ & $294(90)$ & $279(26)$ & $205(100)$ & $189(12)$ & $131(31)$ \\
\hline $\mathrm{C} 3$ & $308(100)$ & $293(80)$ & $219(70)$ & & \\
\hline \multicolumn{6}{|c|}{ Dibenzothiophenols } \\
\hline $\mathrm{CO}$ & 272 & $257(8)$ & $168(100)$ & $103(30)$ & \\
\hline $\mathrm{Cl}$ & $286(44)$ & 271 & $197(100)$ & $165(15)$ & $73(33)$ \\
\hline $\mathrm{C} 2$ & $300(67)$ & $286(36)$ & $269(100)$ & $254(44)$ & \\
\hline $\mathrm{C} 3$ & $314(25)$ & $299(10)$ & $283(100)$ & $225(25)$ & $73(42)$ \\
\hline \multicolumn{6}{|c|}{ Dibenzofuranols } \\
\hline $\mathrm{CO}$ & $256(47)$ & 241 & $211(54)$ & $167(100)$ & \\
\hline $\mathrm{C} 1$ & $270(52)$ & $225(37)$ & $181(100)$ & $73(41)$ & \\
\hline $\mathrm{C} 2$ & $284(35)$ & $268(100)$ & $195(50)$ & $179(45)$ & $73(55)$ \\
\hline C3 & $298(25)$ & $283(19)$ & $266(75)$ & $195(27)$ & $73(100)$ \\
\hline \multicolumn{6}{|c|}{ Pyrenols/Benzofluoranthenols } \\
\hline $\mathrm{CO}$ & $290(100)$ & $275(29)$ & $259(30)$ & $73(49)$ & \\
\hline C1 & $304(100)$ & $289(26)$ & $73(57)$ & & \\
\hline $\mathrm{C} 2$ & 318 & $303(100)$ & $165(66)$ & & \\
\hline \multicolumn{6}{|l|}{ Chrysenols } \\
\hline $\mathrm{CO}$ & $316(40)$ & $301(12)$ & $205(20)$ & $73(100)$ & \\
\hline $\mathrm{Cl}$ & $330(100)$ & $315(35)$ & & & \\
\hline $\mathrm{C} 2$ & $344(100)$ & & & & \\
\hline \multicolumn{6}{|c|}{ BaP/Benzofluoranthenols } \\
\hline $\mathrm{CO}$ & $340(100)$ & & & & \\
\hline $\mathrm{C} 1$ & $354(100)$ & & & & \\
\hline $\mathrm{C} 2$ & $368(100)$ & $353(52)$ & $73(77)$ & & \\
\hline C3 & $382(100)$ & & & & \\
\hline
\end{tabular}

a : molecular ions of PAH metabolites

b: unsubstituted PAH metabolites

${ }^{c}$ : relative intensities of the ion as percentage of the primary ion (with $100 \%$ of the intensity)

d: alkylated PAH metabolites with one methyl substitutent

${ }^{e}$ : alkylayted PAH metabolites with two methyl substitutents or one ethyl substituent

${ }^{f}$ : alkylated PAH metabolites with three methyl substitutents or one ethyl and two methyl substituents or one propyl substituent

and/or sulfate conjugates (Stein et al. 1984). Bile samples (100 $\mu$ l) were treated with 2,000 units $\beta$-glucuronidase (containing 20 units of sulfatase activity) dissolved in $1 \mathrm{ml}$ of $0.4 \mathrm{M}$ acetate buffer ( $\mathrm{pH} \mathrm{5.0)}$ ). Surrogate standard containing 2,6-dibromophenol, 1-naphthol- $\mathrm{d}_{8}$, phenanthrene- $\mathrm{d}_{10}$, and chrysene- $\mathrm{d}_{12}(10.0 \mathrm{ng} / \mu \mathrm{l})$ was added, and the mixture was incubated in a DB-1 Dri-Block at $40^{\circ} \mathrm{C}$ for two hours. The sample was extracted with a solvent mixture consisting of $1 \mathrm{ml}$ methylene chloride $\left(\mathrm{CH}_{2} \mathrm{Cl}_{2}\right)$ and $100 \mu$ methanol $\left(\mathrm{CH}_{3} \mathrm{OH}\right)$. Two additional extractions with $1 \mathrm{ml}$ methylene chloride each were performed. The combined extract was dried with $0.1 \mathrm{~g}$ anhydrous sodium sulfate $\left(\mathrm{Na}_{2} \mathrm{SO}_{4}\right)$, concentrated under a stream of nitrogen and transferred to an HPLC V-vial capped with Teflon-lined cap for GPC HPLC cleanup.
This fraction contained glucuronides and sulfates. Glutathion conjugates remaining in the aqueous phase were recovered by acidic hydrolysis described below.

The aqueous phase was treated with $0.1 \mathrm{~N}$ hydrochloric acid $(\mathrm{HCl})$ to adjust the $\mathrm{pH}$ to 1.0 and hydrolyze glutathion conjugates. The hydrolysis was conducted at ambient temperature. A surrogate standard containing 1-naphthol- $d_{8}$, phenanthrene- $d_{10}$, and chrysene- $d_{12}(10.0 \mathrm{ng} /$ $\mu 1$ ) was added before the sample was extracted three times with $1 \mathrm{ml}$ methylene chloride each time. The combined extracts containing metabolites hydrolyzed from glutathion conjugates were then dried with 1 $\mathrm{g}$ anhydrous sodium sulfate $\left(\mathrm{Na}_{2} \mathrm{SO}_{4}\right)$, concentrated, and further purified by GPC HPLC. 

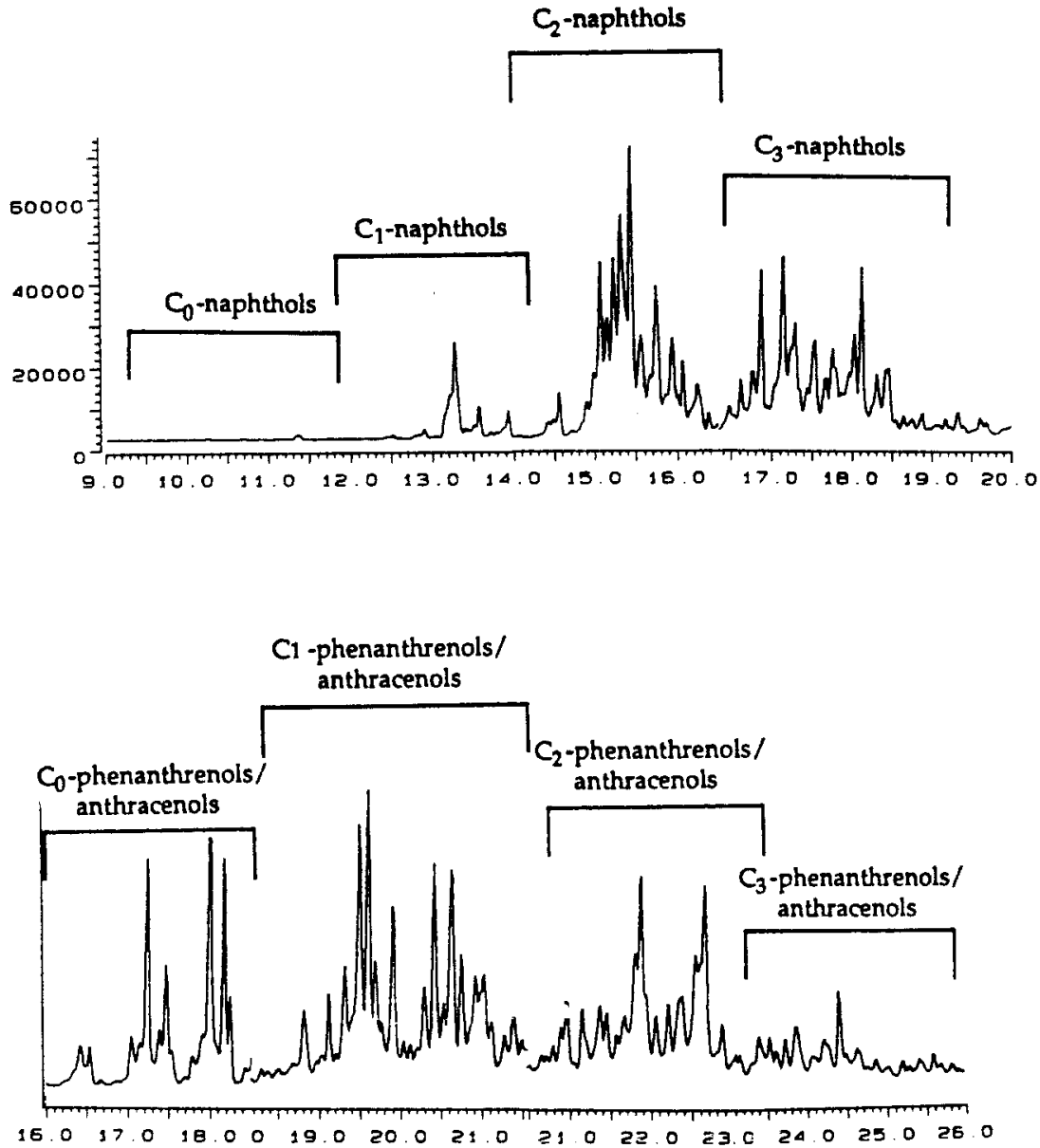

Fig. 1. Mass fragmentograms of naphthols (a) and phenanthrenols/anthracenols (b) in fish bile sampled $120 \mathrm{~h}$ after intramuscular injection of Diesel Fuel Arctic

\section{GPC HPLC Clean-up of Extracts}

The concentrated bile extracts from enzyme hydrolysis or from acidic hydrolysis were processed by GPC HPLC to remove lipids. The HPLC conditions used were modified from those reported by Krahn et al. (1992) for the separation of the PAH metabolites from biogenic material in the extracts after hydrolysis. A flow rate of $7 \mathrm{ml} / \mathrm{min}$ for the mobile phase (methylene chloride) was employed and the collection time for the metabolites started at the elution time of biphenyl and ended based on the elution time of 1-hydroxybenzo[a]pyrene. The HPLC analysis was performed at ambient temperature.

\section{GC/MS Analysis of PAH Metabolites}

Polycyclic aromatic hydrocarbon metabolites were converted to their corresponding trimethylsilyl (TMS) derivatives by sylating the PAH metabolites after the HPLC purification with bis(trimethylsilyl-fluoro) acetaminde (BSTFA). The derivatization took place at $70^{\circ} \mathrm{C}$ for $1.5 \mathrm{~h}$ in a GC conical vial capped loosely. After completion of derivatization, the sample was cooled to ambient temperature and concentrated under a stream of nitrogen. GC internal standards $(100 \mu 1)$ fluorene- $d_{10}$ and benzo[a]pyrene- $\mathrm{d}_{12}(0.50 \mathrm{ng} / \mu \mathrm{l})$ were added. The final sample was evaporated to $100 \mu \mathrm{l}$ with a gentle stream of nitrogen before GC/MS analysis.

Two microliters of derivatized PAH metabolites were injected in the splitless mode into the HP 5985 GC/MS linked with an HP1000 (RTE-6) data system. A J\&W Scientific Durabond DB-5MS fused silica capillary column $(30 \mathrm{~m} \times 0.25 \mathrm{~mm}$ i.d. $)$ was used for all analyses with the oven temperature programmed from $60^{\circ} \mathrm{C}$ at a rate of
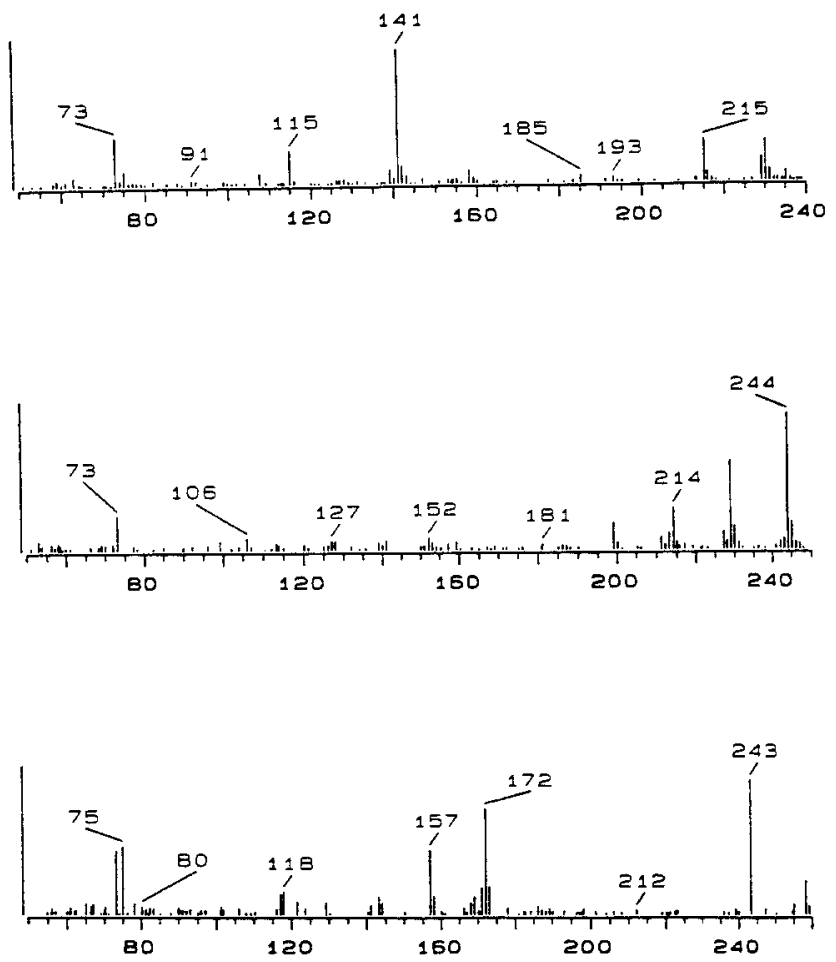

Fig. 2. Mass spectra of naphthols: (a) $\mathrm{C}_{1}$ naphthols $(\mathrm{m} / \mathrm{z}=230)$; (b) $\mathrm{C}_{2}$ naphthols $(\mathrm{m} / \mathrm{z}=244)$; and $(\mathrm{c}) \mathrm{C}_{3}$ naphthols $(\mathrm{m} / \mathrm{z}=258)$ 


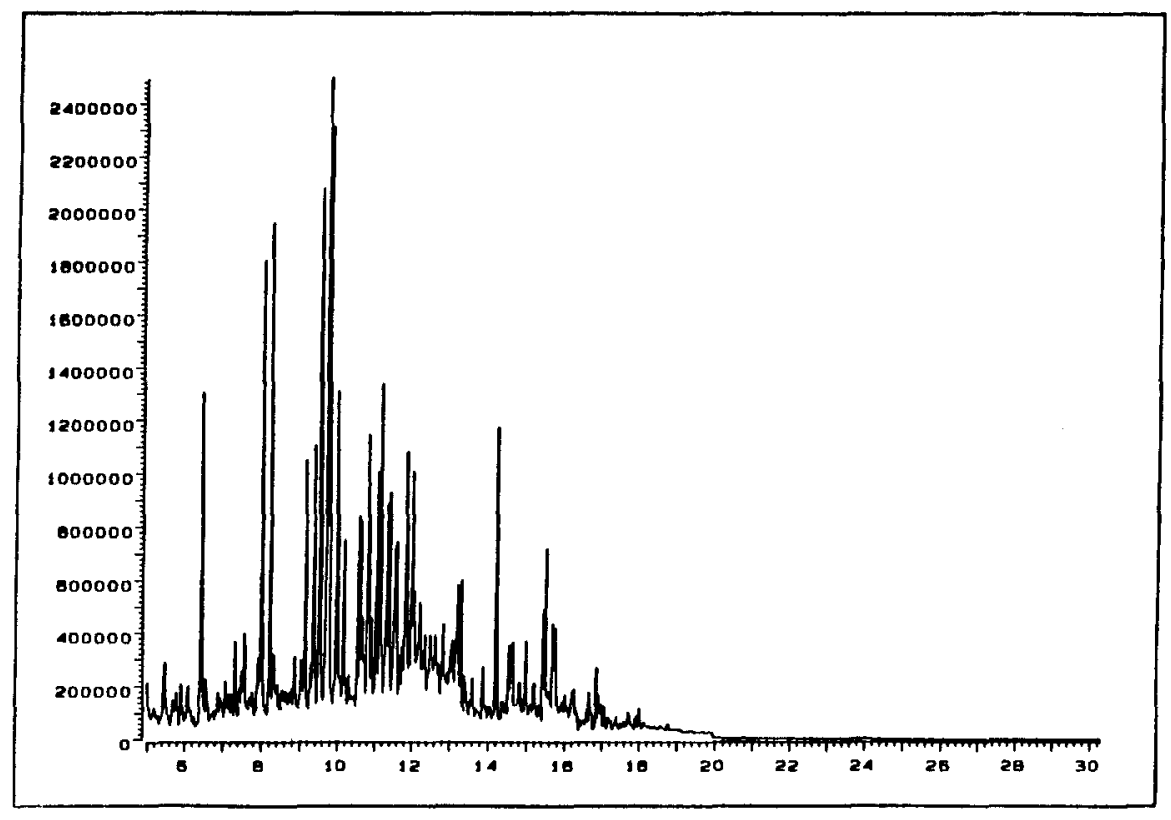

Fig. 3. Total ion chromatogram (TIC) of Diesel Fuel Arctic (DFA)

$15^{\circ} \mathrm{C} / \mathrm{min}$ to $130^{\circ} \mathrm{C}$ with initial holding at $60^{\circ} \mathrm{C}$ for $1 \mathrm{~min}$, then from $130^{\circ} \mathrm{C}$ to $300^{\circ} \mathrm{C}$ at a rate of $5^{\circ} \mathrm{C} / \mathrm{min}$ holding at $300^{\circ} \mathrm{C}$ for $5 \mathrm{~min}$. The total running time was 45 minutes. The injector temperature was $300^{\circ} \mathrm{C}$ and the interface temperature was $280^{\circ} \mathrm{C}$. The effluent from the $\mathrm{GC}$ capillary column was fed directly into the ion source $\left(220^{\circ} \mathrm{C}\right)$ of the mass spectrometer. Selective ion monitoring (SIM) was routinely employed to acquire higher sensitivity. A full scan run was performed on most samples to confim the SIM analysis results.

\section{Identification and Quantification of PAH Metabolites}

Polycyclic aromatic hydrocarbon metabolites were tentatively identified by comparing retention times and mass spectra for each metabolite to (a) retention time of reference standards where available or (b) the published spectra (Takahashi et al. 1979; Jacob and Grimmer 1985; Krahn et al. 1992) or (c) interpretation of the mass spectrum. In addition, identification of some metabolites, particularly those of the $\mathrm{C}_{2}-\mathrm{C}_{3}$ alkylated PAHs, high molecular weight PAHs, was based on the molecular ion and on fragmentation patterns. The identification of the metabolites was based on the characteristic fragment ions of the compounds (Table 1).

The absolute quantitation of individual metabolites was based on GC/MS response relative to that of surrogate standard. The GC/MS was initially calibrated by duplicate injections of standard at different concentrations. The concentration of each compound was calculated based on $d_{8}$-naphthol, a surrogate standard. The molecular ions of PAH metabolites were used as the quantification ions. In a few cases where the molecular ion has a low intensity, a distinct fragment ion was used for quantification. For instance, fragment ion $(\mathrm{m} / \mathrm{z}=208)$, rather than the molecular ion of $d_{8}$-naphthol $(\mathrm{mz}=223)$, was used for quantification due to the very high intensity of fragment ion $\mathrm{m} / \mathrm{z}=208$.

\section{Results and Discussion}

\section{Mass Chromatogram of PAH Metabolites}

The trimethylsilyl (TMS) derivatives of PAH metabolites were well resolved. Mass fragmentograms of homologue series $\left(\mathrm{C}_{0^{-}}\right.$ $\mathrm{C}_{3}$ ) of naphthols and phenanthrenols/anthracenols are presented
Table 2. Polycyclic aromatic hydrocarbon (PAH) composition of Diesel Fuel Arctic determined by GC-MS

\begin{tabular}{|c|c|c|}
\hline Compound & $\begin{array}{l}\text { concentration } \\
\text { (ng/g) }\end{array}$ & $\Sigma \mathrm{C}_{\mathrm{x}} / \Sigma \mathrm{C}_{0}$ \\
\hline naphthalene & 995.78 & 7.3 \\
\hline 1-methylnaphthalene & 1395.73 & \\
\hline 2-methylnaphthalene & 1267.90 & \\
\hline $\mathrm{C}_{2}$-naphthalene & 2461.47 & \\
\hline $\mathrm{C}_{3}$-naphthalene & 1525.78 & \\
\hline $\mathrm{C}_{4}$-naphthalene & 652.44 & \\
\hline biphenyl & 541.58 & \\
\hline fluorene & 472.74 & 3.4 \\
\hline $\mathrm{C}_{1}$-fluorene & 618.86 & \\
\hline $\mathrm{C}_{2}$-fluorene & 607.45 & \\
\hline $\mathrm{C}_{3}$-fluorene & 372.29 & \\
\hline phenanthrene & 570.61 & 1.9 \\
\hline anthracene & 19.82 & \\
\hline $\mathrm{C}_{1}$-phenanthrene/anthracene & 625.06 & \\
\hline $\mathrm{C}_{2}$-phenanthrene/anthracene & 359.66 & \\
\hline $\mathrm{C}_{3}$-phenanthrene/anthracene & 105.97 & \\
\hline $\mathrm{C}_{4}$-phenanthrene/anthracene & 37.51 & \\
\hline dibenzothiophene & 79.32 & 3.6 \\
\hline $\mathrm{C}_{1}$-dibenzothiophene & 126.36 & \\
\hline $\mathrm{C}_{2}$-dibenzothiophene & 100.92 & \\
\hline $\mathrm{C}_{3}$-dibenzothiophene & 58.41 & \\
\hline pyrene & 18.45 & 0.2 \\
\hline fluoranthene & 5.62 & \\
\hline $\mathrm{C}_{1}$-pyrenes/fluoranthenes & 4.24 & \\
\hline chrysene & 3.21 & 0.9 \\
\hline benz[a]anthracene & 0.58 & \\
\hline $\mathrm{C}_{1}$-chrysene/benzanthracene & 1.88 & \\
\hline $\mathrm{C}_{2}$-chrysene/benzanthracene & 1.54 & \\
\hline$\Sigma \mathrm{C}_{0}$ & 2707.71 & \\
\hline$\Sigma C_{x}$ & 10324.47 & \\
\hline$\Sigma C_{x} / \Sigma C_{0}$ & 3.8 & \\
\hline
\end{tabular}

in Figure 1. The structure of various isomeric hydroxyl metabolites, due to limited availability of reference standards, could not be established based solely on their mass spectra. However, 


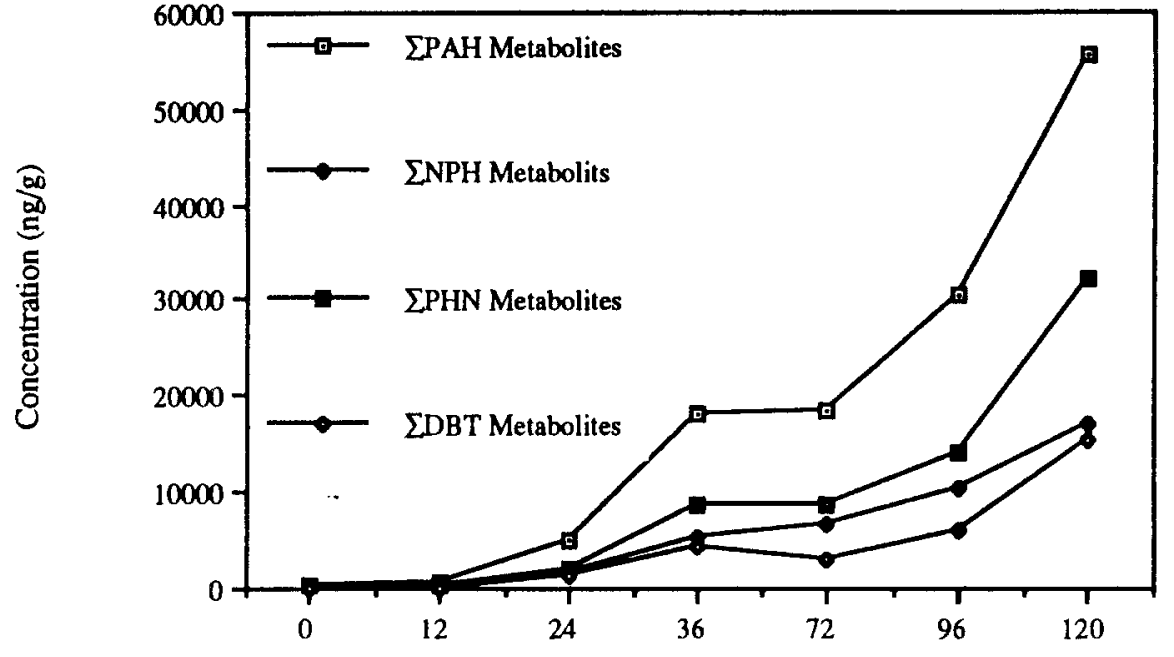

Exposure Time (hours)
Fig. 4. The response curve: concentrations of total PAH metabolites ( $\Sigma$ PAH), phenanthreols/anthracenols ( $\Sigma \mathrm{PHN})$, naphthols ( $\Sigma N P H)$, and dibenzothiophenols ( $\mathrm{DDBT}$ ) detected in fish bile are plotted against exposure time (hours). A Sigmoid curve is the result. See text for discussion

Table 3. Concentration of polycyclic aromatic hydrocarbon (PAH) metabolites detected by GC/MS in Antarctic fish (Notothenia gibberifrons) injected with Diesel Fuel Arctic

\begin{tabular}{|c|c|c|c|c|c|c|c|c|}
\hline \multirow{2}{*}{$\begin{array}{l}\text { Exposure } \\
\text { time } \\
\text { (h) }\end{array}$} & \multicolumn{8}{|c|}{ Metabolite concentration (ng/g) } \\
\hline & $\Sigma \mathrm{NPH}^{*}$ & $\Sigma \mathrm{DBT}$ & $\sum \mathrm{PHN}$ & $\Sigma \mathrm{PAH}$ & $\Sigma \mathrm{C}_{0}$ & $\Sigma \mathrm{C}_{\mathrm{x}}$ & $\left(\Sigma \mathrm{C}_{\mathrm{x}} / \Sigma \mathrm{C}_{0}\right)_{\text {met. }}$ & $\begin{array}{l}\left(\Sigma \mathrm{C}_{\mathrm{x}} / \Sigma \mathrm{C}_{0}\right)_{\text {met. }} \\
\left(\Sigma \mathrm{C}_{\mathrm{x}} / \Sigma \mathrm{C}_{0}\right)_{\text {oil }}\end{array}$ \\
\hline 0 & 195.3 & 23.0 & 249.0 & 467.2 & 66.6 & 400.7 & 6.0 & 1.6 \\
\hline 12 & 176.5 & 111.6 & 379.0 & 667.1 & 39.1 & 628.0 & 16.1 & 4.2 \\
\hline 24 & 1544.4 & 1291.0 & 2154.7 & 4990.0 & 167.8 & 4822.2 & 28.7 & 7.6 \\
\hline 36 & 5331.6 & 4226.8 & 8582.4 & 18140.8 & 682.0 & 17458.8 & 25.6 & 6.7 \\
\hline 72 & 6777.2 & 2865.2 & 8839.9 & 18482.3 & 401.6 & 17080.7 & 42.5 & 11.2 \\
\hline 96 & 10413.9 & 5976.4 & 14110.4 & 30500.7 & 2142.1 & 28358.6 & 13.2 & 3.5 \\
\hline 120 & 16941.6 & 15428.4 & 32225.3 & 55737.9 & 5287.1 & 50450.9 & 9.5 & 2.5 \\
\hline
\end{tabular}

$* \Sigma N P H:$ total $\mathrm{C}_{0}-\mathrm{C}_{3}$ naphthols; $\Sigma \mathrm{DBT}$ : total $\mathrm{C}_{0}-\mathrm{C}_{3}$ dibenzothiophenols; $\Sigma \mathrm{PHN}$ : total $\mathrm{C}_{0}-\mathrm{C}_{3}$ phenanthrenols/anthracenols: $\Sigma \mathrm{PAH}$ : total PAH metabolites; $\Sigma C_{0}$ : total unsubstituted PAH metabolites; $\Sigma C_{x}$ total alkylated PAH metabolite; $\left(\Sigma C_{x} / \Sigma C_{0}\right)_{\text {met }}:$ ratio of total alkylated PAH metabolites over total unsubstituted PAH metabolites; $\left.\left(\Sigma \mathrm{C}_{\mathrm{x}} / \Sigma \mathrm{C}_{0}\right)_{\text {met. }} / \Sigma \mathrm{C}_{\mathrm{x}} / \mathrm{C}_{0}\right)_{\mathrm{oil}}$ : comparison of the ratio of total alkylated PAH metabolites over unsubstituted PAH metabolites to that of the oil to which the fish were exposed

the identity of each metabolite series $\left(\mathrm{C}_{0}, \mathrm{C}_{1}, \mathrm{C}_{2}\right.$, and $\left.\mathrm{C}_{3}\right)$ was readily assigned from interpretation of their mass spectra.

The TMS-ethers of PAH metabolites are characterized by a prominent molecular ion (Table 1, Figure 2) which appears as either a base peak, or peak with over $40 \%$ abundance compared to the base peak on mass spectrum. Other major fragment ions include $\mathrm{M}^{+}-15$ and $\mathrm{M}^{+}-31$. A strong $\mathrm{M}^{+}-89$ ion [-OTMS, i.e., $\left.-\mathrm{O}-\mathrm{Si}\left(\mathrm{CH}_{3}\right)_{3}\right]$ indicates the presence of a hydroxyl group.

\section{Diesel Fuel Arctic (DFA)}

Diesel Fuel Arctic (DFA) is a refined oil that is enriched in naphthalene and its alkylated $\left(C_{x}\right)$ derivatives, with lesser amounts of $\mathrm{C}_{0}$ (parent compounds) and $\mathrm{C}_{\mathrm{x}}$ phenanthrene/ anthracene and dibenzothiophene (Kennicutt et al. 1991, 1992; Figure 3).

\section{Polycyclic Aromatic Hydrocarbon Biliary Metabolites from Notothenia gibberifrons}

Concentrations of PAH metabolites measured in fish by the GC/MS method after i.m. injection of DFA at a dose level of
$100 \mu \mathrm{l}$ are shown in Table 2. The results of the dose-response study showed that PAH metabolites were produced within $24 \mathrm{~h}$ after i.m. injection of DFA into Notothenia gibberifrons. The variations of concentrations of NPH, PHN, DBT, and total $\mathrm{PAH}$ are presented in Figure 4. The plot resembles a Sigmoid curve, consisting of an initial low-level response at $24 \mathrm{~h}$ followed by a rapid rise in production of $\mathrm{PAH}$ metabolites up to $120 \mathrm{~h}$ (Figure 4). The rise phase was steep; for instance, the production of PAH metabolites increased from $30.50 \mu \mathrm{g} / \mathrm{g}$ in $\Sigma \mathrm{PAH}$ at $96 \mathrm{~h}$, to $55.74 \mu \mathrm{g} / \mathrm{g}$ at $120 \mathrm{~h}$, an increase of 1.8 -fold. The PAH composition of the DFA was predominated by naphthalene and its alkylated components (Kennicutt et al. 1991, 1992). However, the PAH metabolite analysis results (Table 3 , Figure 4) suggest that the production rate of metabolites was higher for phenanthrene compared to naphthalene. The cause for this phenomenon is not year clear. English sole exposed simultaneously to naphthalene and $\mathrm{BaP}$ metabolized $\mathrm{BaP}$ to a greater extent than naphthalene; the ratios of $\mathrm{BaP}$ metabolites detected to $\mathrm{BaP}$ and naphthalene metabolites to naphthalene were, respectively, $49: 1$ and $6: 1$ at $24 \mathrm{~h}$ after exposure (Varanasi and Gmur 1981). Phenanthrenes/anthracenes, as a higher ring PAH (3-ring) than naphthalene, could be metabolized more extensively than naphthalene by the Antarctic fish, simi- 


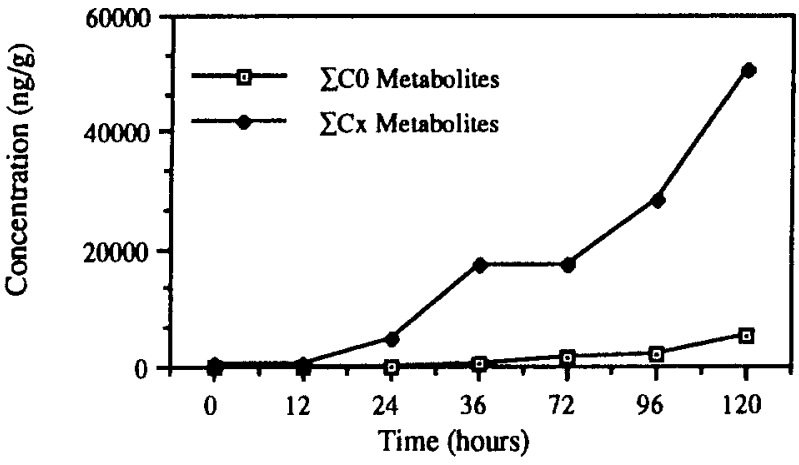

Fig. 5. Plot of the concentration of $C_{0}$ (total unsubstituted PAH metabolites) and $\mathrm{C}_{\mathrm{x}}$ (total alkylated $\mathrm{PAH}$ metabolites) against exposure time (hour). $C_{x}$ increased rapidly after $12 \mathrm{~h}$, whereas $C_{0}$ increased only slightly

lar to $\mathrm{BaP}$, where higher ring PAH (5-ring) were metabolized more extensively than naphthalene by English sole (Varanasi and Gmur 1981).

Alkyl substituted PAH metabolites $\left(\mathrm{C}_{\mathrm{x}}\right)$ are much higher in concentration than unsubstituted ones $\left(\mathrm{C}_{0}\right)$ (Figure 5). The ratio of $\mathrm{C}_{\mathrm{x}} / \mathrm{C}_{0}$ of metabolites detected in the fish bile ranged from 6.0 to 42.5 (Table 2), compared with DFA, whose $\mathrm{C}_{\mathrm{x}} / \mathrm{C}_{0}$ ratio is 3.8; the $\mathrm{C}_{\mathrm{x}}$ metabolites detected in fish were enriched from 1.8 to 12.9 fold. The concentrations of $C_{x}$ metabolites show a rapid increase, whereas those of $\mathrm{C}_{0}$ increased only slowly during the exposure period (Figure 5). This phenomenon may reflect the nature of the exposed petroleum (DFA). The $\mathrm{C}_{\mathrm{x}} \mathrm{PAH}$ of the DFA are 3.3 times higher than the $\mathrm{C}_{0}$ PAH. It is also likely that the distribution pattern reflects the selectivity of metabolism and excretion (DiGiovanni and Juchau 1980), i.e., fish may preferentially metabolize alkyl-subtituted aromatic hydrocarbons. Examination of Table 2 indicates that ratios of $\Sigma C_{x} / \Sigma C_{0}$ metabolites are much higher than the ratios of $\Sigma \mathrm{C}_{\mathrm{x}} / \Sigma \mathrm{C}_{0}$ of parent hydrocarbons, particularly during the period of rapid rise in the production of PAH metabolites (Figure 4). This indicates the preferential metabolism of alkylated hydrocarbons by fish.

Krahn et al. (1992) were successful in using HPLC/ fluorescence and GC/MS methods to detect PAH metabolites in fish exposed to petroleum after the Exxon Valdez oil spill. Hellou and Payne (1987) demonstrated in laboratory studies with trout exposed to water-soluble fractions or petroleum that detection of conjugated metabolites in the gallbladder bile of fish can provide a rapid investigative tool for assessment of petroleum and fuel oil pollution. The present study provides further support for the use of PAH metabolites in bile as monitoring indicators of $\mathrm{PAH}$ exposure in fish.

\section{Conclusions}

Antarctic fish (Notothenia gibberifrons) that were administered petroleum hydrocarbons (DFA) produced PAH metabo- lites within $24 \mathrm{~h}$ of exposure. Production of PAH metabolites was generally proportional to exposure time. After an initial lag period $(0-12 \mathrm{~h})$, the production of PAH metabolites stated at 24 $h$ and maintained a steady concentration from $36 \mathrm{~h}$ to $72 \mathrm{~h}$, followed by a rapid rise in concentration at $72 \mathrm{~h}$. Fish bile was not obtained after $120 \mathrm{~h}$. However, the findings in this study suggest that fish respond to $\mathrm{PAH}$ contamination by producing PAH metabolites. Therefore, the detection of PAH metabolites by GC/MS can provide a ready tool for monitoring and assessment studies.

\section{References}

DiGiovanni J, Juchau MR (1980) Biotransformation and bioactivation of 7,12-dimethylbenz[a]anthracene (7,12 DMBA). Drug Metab Rev 11:61-101

Hellou J, Payne JF (1978) Assessment of contamination of fish by water-soluble fractions of petroleum: A role for bile metabolites. Arch Enviroin Contam Toxicol 6:857-862

Jacob J, Grimmer G (1985) Capillary gas chromatographical analysis and mass spectrometric identification of polycyclic aromatic hydrocarbon metabolites from biological materials. In: Cook M, Dennis AJ (eds) Polynuclear aromatic hydrocarbons: Formation metabolism and measurement. Battelle Press, Columbus, $\mathrm{OH}, \mathrm{pp}$ 49-89

Kennucitt MC II, Sweet ST, Fraser WR, Stockton WL, Culver M (1991) Grouding of the Bahia Paraiso at Arthur Harbor, Antarctica. 1. Distribution and fate of oil spill related hydrocarbons. Environ Sci Technol 25:509-518

Kennicutt MC II, McDonald TJ, Denoux GJ, McDonald SJ (1992). Hydrocarbon contamination on the Antarctic Peninsula I. Arthur Harbor-Subtidal sediments. Marine Pollut Biol 24(10):499-506

Krahn MM, Burrows DG, Ylitalo GM, Brown DW, Wigrin CA, Collier TK, Chan S-L, Varanasi U (1992) Mass spectrometric analysis for aromatic compounds in bile of fish sampled after the Exxon Valdez oil spill. Environ Sci Technol 26:116-126

Livingston DR (1993) Biotechnology and pollution monitoring: Use of molecular biomarkers in the aquatic environment. J Chem Technol Biotechnol 57:195-211

McDonald SJ, Kennicutt MC II, Brooks JM (1992) Evidence of polycyclic aromatic hydrocarbon (PAH) exposure in fish from the Antarctic Peninsula. Marine Pollut Biol 25(9-12):313-317

Stein JE, Hom T, Varanasi U (1984) Simultaneous exposure of English sole (Parophrys vetulus) to sediment-associated xenobiotics: Part I-Uptake and disposition of 14C-polychlorinated biphenyls and 3H-benzo[a]yrene. Mar Environ Res 13:97-119

Takahashi G, Kinoshita K, Hashimoto K, Yasuhira K (1979) Identification of benzo[a]pyrene metabolites by gas chromatograph-mass spectrometer. Cancer Res 39:1814-1818

Varanasi U, Gmur DH (1980) Metabolic activation and covalent binding of benzo[a]pyrene to deoxyribonucleic acid catalyzed by liver enzymes of marine fish. Biochem Pharmacol 29:753-758

Varanasi U, Gmur DH (1981) Hydrocarbons and metabolites in English sole (Parophrys vetulus) exposed simultaneously to $\left[{ }^{3} \mathrm{H}\right]$ benzo[a]pyrene and $\left[{ }^{14} \mathrm{C}\right]$ naphthalene in oil-contaminated sediment. Aquat Toxicol 1:49-53

$\mathrm{Yu}$ Y (1994) Gas chroamtography/mass spectrometry detection of polycyclic aromatic hydrocarbon metabolites in fish and its application in environmental studies. PhD Dissertation, Texas A\&M University, College Station, TX 